\title{
Structure-activity relationship of uniconazole, a potent inhibitor of ABA 8'-hydroxylase, with a focus on hydrophilic functional groups and conformation
}

Yasushi Todoroki, ${ }^{\mathrm{a}, *}$ Kyotaro Kobayashi, ${ }^{\text {a }}$ Hidetaka Yoneyama, ${ }^{\mathrm{a}}$ Saori Hiramatsu, ${ }^{\mathrm{a}}$ Mei-Hong Jin, ${ }^{\mathrm{a}}$ Bunta Watanabe, ${ }^{b, \dagger}$ Masaharu Mizutani, ${ }^{b}$ and Nobuhiro Hirai ${ }^{c}$

${ }^{a}$ Department of Applied Biological Chemistry, Faculty of Agriculture, Shizuoka University, Shizuoka 422-8529, Japan

${ }^{\mathrm{b}}$ Institute for Chemical Research, Kyoto University, Uji, Kyoto 611-0011, Japan

${ }^{\mathrm{c}}$ Division of Environmental Science and Technology, Graduate School of Agriculture, Kyoto University, Kyoto 606-8501, Japan

* Corresponding author. Phone\&Fax: +81-54-238-4871. E-mail: aytodor@agr.shizuoka.ac.jp

† Present address: Sagami Chemical Research Center, 2743-1 Hayakawa, Ayase, Kanagawa 252-1193, Japan. 


\begin{abstract}
The plant growth retardant $S-(+)$-uniconazole (UNI-OH) is a strong inhibitor of abscisic acid (ABA) 8'hydroxylase, a key enzyme in the catabolism of ABA, a plant hormone involved in stress tolerance, stomatal closure, flowering, seed dormancy, and other physiological events. In the present study, we focused on the two polar sites of UNI-OH and synthesized 3- and 2"-modified analogs. Conformational analysis and an in vitro enzyme inhibition assay yielded new findings on the structureactivity relationship of UNI-OH: (1) by substituting imidazole for triazole, which increases affinity to heme iron, we identified a more potent compound, IMI-OH; (2) the polar group at the 3-position increases affinity for the active site by electrostatic or hydrogen-bonding interactions; (3) the conformer preference for a polar environment partially contributes to affinity for the active site. These findings should be useful for designing potent azole-containing specific inhibitors of ABA 8'hydroxylase.
\end{abstract}




\section{Introduction}

Uniconazole [S-(+)-E-1-(4-chlorophenyl)-4,4-dimethyl-2-(1,2,4-triazo-1-yl)-1-penten-3-ol, UNI-OH] is an azole-containing P450 inhibitor developed as a plant growth retardant in the 1980 's. ${ }^{1,2} \mathrm{UNI}-\mathrm{OH}$ has since been used as a plant growth regulator in agriculture and horticulture. The main site of action of UNI-OH is suggested to be ent-kaurene oxidase, which catalyzes the three-step oxidation of entkaurene to ent-kaurenoic acid, ${ }^{3}$ biosynthetic precursors of the plant hormone gibberellin (GA). This has prompted researchers to use UNI-OH as a chemical tool inhibiting GA biosynthesis. However, UNI-OH also inhibits brassinosteroid (BR) biosynthesis, ${ }^{4,5}$ and alters the level of other plant hormones, such as auxins, cytokinins, ethylene and abscisic acid (ABA). ${ }^{6}$ Recently, Kitahata et al. ${ }^{7}$ and Saito et al. ${ }^{8}$ revealed that UNI-OH strongly inhibits ABA 8'-hydroxylase, a key enzyme in ABA catabolism (Figure 1).

ABA is the classical plant hormone involved in stress tolerance, stomatal closure, flowering, seed dormancy, and other physiological events. ${ }^{9-11}$ In addition, it was reported recently that ABA functions as an endogenous proinflammatory cytokine in humans. ${ }^{12}$ Proper endogenous levels of ABA in plants are cooperatively controlled by biosynthesis, transportation, and catabolic inactivation in response to environmental changes. ${ }^{9-11}$ A natural or artificial chemical that perturbs this highly controlled system is promising not only as a chemical probe for the mechanism of ABA action, ${ }^{13}$ but also for its potential agricultural, horticultural, and clinical use. Catabolic inactivation of ABA is mainly controlled by ABA 8'-hydroxylase, which is the cytochrome P450 catalyzing the C8'-hydroxylation of ABA into 8'hydroxy-ABA and its more stable tautomer phaseic acid, which has much lower hormonal activity than ABA. $^{14}$ ABA 8'-hydroxylase was identified as CYP707A1-4 in the model plant Arabidopsis thaliana in $2004,{ }^{15,16}$ and since then CYP707A isozymes have been found in various plants. ${ }^{17-20}$ Gene knockdown and overexpression studies suggest that ABA 8'-hydroxylase is a key enzyme controlling 
ABA concentration during water deficit stress and dormancy. ${ }^{21,22}$ UNI-OH inhibits ABA 8'hydroxylase at a very low concentration: its $K_{\mathrm{I}}$ value was $8 \mathrm{nM}$ in an in vitro assay. ${ }^{8}$ UNI-OH-treated plants have enhanced drought tolerance due to two-fold higher accumulation of endogenous ABA than untreated plants. $^{8}$ Thus, UNI-OH is a good inhibitor of ABA 8'-hydroxylase, though it has side effects such as inhibition of GA and BR biosynthesis.

Azole-type inhibitors bind to P450 active sites by both coordinating to the heme-iron atom and interacting with surrounding protein residues. Because heme coordination is a common property of azole-containing inhibitors, their affinity and specificity for individual P450 enzymes depends on structural properties other than the azole group. To develop a specific inhibitor of ABA 8'-hydroxylase by structural modification of UNI-OH, the structure-activity relationship of UNI-OH should be revealed in detail. Kitahata et al. investigated the structure-activity relationship of UNI-OH by focusing on the two lipophilic substituents, the tert-butyl at the 3-position and 4-chlorophenyl group at the 1-position, ${ }^{7}$ revealing that these functional groups are essential for inhibiting ABA 8'-hydroxylase and should not be modified in the lead optimization phase. Other functional groups have not been examined.

In the present study, we focused on the two hydrophilic functional groups of UNI-OH, the aza-nitrogen (N2") and the hydroxy group at the 3-position. The electrostatic or hydrogen-bonding interactions mediated by these groups can affect not only electrostatic interactions with the active site but also conformational properties. In fact, Katagi et al. reported, based on ${ }^{1} \mathrm{H}$ NMR and IR analyses, that UNI$\mathrm{OH}$ adopts conformer $\mathbf{A}$ in nonpolar or weakly polar solvents (Figure 2) by the formation of an intramolecular hydrogen bond between the 3-hydroxy and N2". ${ }^{23}$ We designed UNI-X and IMI-X (X = $\mathrm{OH}, \mathrm{OMe}, \mathrm{F}$, and $\mathrm{H}$ ) (Figure 3) as probes to explore the role of the 3-hydroxy and N2" of UNI-OH in binding to ABA 8'-hydroxylase. The hydroxy group can act as both a donor and an acceptor in a 
hydrogen bond, whereas the methoxy group can act only as an acceptor. Fluorine can act only as a weaker acceptor than hydroxy and methoxy groups. The aliphatic hydrogen can be neither donor nor acceptor in a conventional hydrogen bond. The introduction of a carbon at the 2"-position can eliminate the intramolecular hydrogen bond. Although UNI-OMe, ${ }^{2} \mathrm{UNI}-\mathrm{H},{ }^{24}$ and IMI-OH ${ }^{25}$ are known compounds, the detailed effects of all optically pure UNI-X and IMI-X containing these known compounds on ABA 8'-hydroxylase have never been reported. These analogs are expected to have different conformational profiles and different interactions with the active site; thus, a comparison between their structure and inhibitory activity against ABA 8'-hydroxylase can reveal the significance of the hydrophilic moieties of UNI-OH in binding to the active site.

\section{Results and Discussion}

\subsection{Synthesis of UNI-OH analogs}

Commercially available UNI-OH, uniconazole-P (Wako Pure Chemical Industries, Ltd.), was a mixture of $S-(+)-$ and $R-(-)-\mathrm{UNI}-\mathrm{OH}$ at a ratio of $89: 11$, based on chiral HPLC analysis; that is, the enantiomeric excess was 79\%. Optically pure $S-(+)-\mathrm{UNI}-\mathrm{OH}(>99 \%$ ee) was obtained by semipreparatory HPLC with a chiral stationary phase. Only the $S$-enantiomers were used in this study because S-UNI-OH and its derivatives (e.g., diniconazole) are effective in plants, whereas the $R$ -

enantiomers are ineffective in plants but act as fungicides. ${ }^{26,27}$ UNI-OMe and UNI-F were synthesized according to Scheme 1. Methylation of uniconazole-P with methyl iodide gave UNI-OMe, which was optically purified by chiral HPLC to give S-(-)-UNI-OMe. Fluorination of uniconazole-P with DAST gave UNI-F, which was a 1:1 mixture of (+)- and (-)-enantiomers, based on chiral HPLC analysis. The reaction also gave the 1-fluorinated compound as a by-product. This result suggests that the fluorination was an $\mathrm{S}_{\mathrm{N}} 1$ reaction in spite of the observation that DAST fluorination favors an $\mathrm{S}_{\mathrm{N}} 2$ 
reaction in most cases. ${ }^{28}$ This is probably because the carbocation intermediate at the 3-position was stabilized by the tert-butyl group and the conjugated system. The racemic UNI-F was separated into each enantiomer by chiral HPLC. The absolute configuration of optically pure UNI-F was determined by X-ray crystalline structure analysis; the (+)- and (-)-enantiomers have the $R$ - and $S$-configurations, respectively. UNI-H was synthesized according to Scheme 2. Aldol condensation of pivaldehyde and 4'-chloroacetophenone gave compound $\mathbf{1}$, which was reduced and brominated to give compound $\mathbf{3}$. A coupling reaction of $\mathbf{3}$ and 1,2,4-1H-triazole gave compound $\mathbf{4}$, which was reduced, brominated, and dehydrobrominated to give UNI-H.

IMI-OH, IMI-OMe, and IMI-F were synthesized according to Scheme 3. A coupling reaction of imidazole and 1-bromo-3,3-dimethylbutan-2-one gave compound 7. Aldol condensation of 7 and 4chlorobenzaldehyde gave the Z-ketone $\mathbf{8 Z}$, which was converted into the E-ketone $\mathbf{8 E}$ by photoisomerization using a single light source at $366 \mathrm{~nm}$. The $E$-ketone $\mathbf{8 E}$ was reduced to give racemic IMI-OH, which was methylated and fluorinated to give racemic IMI-OMe and IMI-F, respectively. IMI-OH, IMI-OMe, and IMI-F were resolved into each enantiomer by chiral HPLC. IMI-H was synthesized in a similar manner to UNI-H, according to Scheme 2. The absolute configuration of IMI-OH was determined by X-ray crystalline structure analysis; the $(+)-$ and $(-)$ enantiomers have the $R$ - and $S$-configurations, respectively. Because methylation of $S$-(-)-IMI-OH gave the (-)-enantiomer of IMI-OMe, the absolute configuration of (-)-IMI-OMe was determined to be $S$. The absolute configuration of optically pure IMI-F, which was not crystallized, was estimated from the pattern of Cotton effects, which was similar to that of optically pure IMI-OH. IMI-OH and IMI-F have the same two chromophores, the imidazole and 4-chlorophenyl. Although these are linked by a $\mathrm{C}=\mathrm{C}$ double bond, the $\mathrm{X}$-ray and theoretical structures of IMI-OH reveal that these are not on the same plane owing to torsion. The 3D orientation of IMI-OH and IMI-F with the same absolute configuration is similar on the basis of the theoretical geometries (Figure 4). Thus these two 
compounds with the same absolute configuration should give similar circular dichroism (CD) spectra. In $\mathrm{CD}$ analysis, the (-)-isomers of IMI-OH and IMI-F gave similar CD spectra: negative first and positive second Cotton effects. Thus, we determined the absolute configurations of (+)- and (-)-IMI-F as $R$ and $S$, respectively.

\subsection{Theoretical conformational analysis}

Because UNI-X and IMI-X have t-butyl and hydrophilic groups at the 3-position, the rotation of the $\mathrm{C} 2-\mathrm{C} 3$ bond has a great effect on the molecular shape and electrostatic distribution. $\mathrm{C} 2-\mathrm{N} 1$ " bond rotation affects the orientation of aza-nitrogens, N2" and N4" for UNI-X and N3" for IMI-X. Because the aza-nitrogen at the 4-position in the triazole ring and the 3-position in the imidazole ring are coordinated with the heme iron at the active site, ${ }^{29}$ the orientation of these nitrogens determines the primary location of UNI-X and IMI-X at the active site. The N2" of UNI-X should affect conformational preference by interaction with the 3 -substituent. Other bond rotations will have only a small effect on the molecular shape, electrostatic distribution, and location within the active site, although they may give many minor conformers. We constructed the four initial geometries, conformers A-D (Figure 2), on the basis of the C2-N2" and C2-C3 bond rotations. The most stable geometries of each conformer were obtained by theoretical calculation using density functional theory. Conformers A-D were fully optimized at the B3LYP/6-31G(d) level of the theory, and single point energies were obtained at B3LYP/6-311++G(2df,2p) with zero-point energy corrections. The geometries and energies in the aqueous phase were calculated respectively using the Onsager and PCM models at the same level of the theory as in the gas phase.

Because conformers $\mathbf{A}$ and $\mathbf{B}$ in UNI-OH were much more stable than conformers $\mathbf{C}$ and $\mathbf{D}$, the populations of which were less than $5 \%$ in both the gas and aqueous phases, we focused on only the A/B population ratio in all the analogs (Table 1). UNI-OH prefers conformer $\mathbf{A}$ in the gas phase but $\mathbf{B}$ 
in the aqueous phase. The result in the gas phase agrees with the MNDO calculation of Katagi et al. ${ }^{23}$ This conformational preference can be explained by the intramolecular hydrogen bond between the 3OH and N2", which contributes to the conformational energy in the gas phase more than in the aqueous phase. UNI-OMe and UNI-F prefer conformer $\mathbf{B}$ in both phases, probably because UNI-OMe and UNI-F have an electrostatic repulsion between the 3-OMe or -F and N2". This repulsion seems to be weakened in the aqueous phase. UNI-H and all the IMI-X types favor A and B equally. Because these analogs have no significant intramolecular hydrogen bond, the conformational preference will not be affected by environmental conditions. For UNI-OH, the energy difference between the most and least stable conformers was calculated to be less than $5.7 \mathrm{kcal} \mathrm{mol}^{-1}$ in the gas phase and $2.9 \mathrm{kcal} \mathrm{mol}^{-1}$ in the aqueous phase, and the energy barriers for the $\mathrm{C} 2-\mathrm{N} 2$ " and $\mathrm{C} 2-\mathrm{C} 3$ bond rotations were estimated to be 8.2 and $11.2 \mathrm{kcal} \mathrm{mol}^{-1}$, respectively.

\subsection{Experimental conformational analysis}

The theoretical estimations for conformational profiles of UNI-X and IMI-X were supported by NOESY correlation experiments (Figure 5). UNI-OH showed a NOEY correlation between the 1-H and 5 "-H in $\mathrm{CDCl}_{3}$. This was not observed in methanol- $d_{4}$, whereas a NOEY correlation between the $t$ butyl protons and 5"-H was observed in this polar solvent. This indicates that UNI-OH prefers conformer $\mathbf{A}$ in the less polar solvent but $\mathbf{B}$ in the polar solvent. UNI-OMe and UNI-F showed an NOE between the t-butyl protons and 5"-H in both $\mathrm{CDCl}_{3}$ and methanol- $d_{4}$. UNI-F showed a throughspace $J$-coupling between the $3-\mathrm{F}$ and $5 "-\mathrm{H}$ in both solvents. These observations indicate that UNIOMe and UNI-F favor conformer B independent of solvent polarity. However, UNI-H and all the IMIX types showed NOEY correlations between the 2" (and 5")-H and t-butyl protons, and between 2" (and 5")-H and 1-H, indicating that they favor conformers $\mathbf{A}$ and $\mathbf{B}$ equally. These results are consistent with the theoretical results. 
The 3D structures of UNI-OH, UNI-F, and IMI-OH, which were able to be crystallized in methanolwater, were elucidated by X-ray crystallographic analysis (Figure 6). All three compounds adopted conformer $\mathbf{B}$ in the crystals. For UNI-OH and UNI-F, this result agrees with the theoretical and NMRbased experimental analyses. IMI-OH, which was predicted to favor $\mathbf{A}$ and $\mathbf{B}$ equally, was packed in the $\mathbf{B}$ form in the crystal. Because an intermolecular hydrogen bond was observed between the 3-OH and N4" in the crystal, this interaction may drive the crystallization of the B-type IMI-OH.

\subsection{Inhibitory potency against ABA 8'-hydroxylase}

All the UNI-X and IMI-X types inhibited ABA 8'-hydroxylase which was obtained from a microsomal fraction of insect cells expressing Arabidopsis CYP707A3. ${ }^{15}$ The S-enantiomers showed competitive inhibition more strongly than the corresponding $R$-enantiomers by a factor of more than 100 (data not shown). The $K_{\mathrm{I}}$ values of all the $S$-enantiomers, UNI-H, and IMI-H are summarized in Table 2 . In the UNI-X types, UNI-OH, which has a hydroxy group at the 3-position, was most effective; the activity decreased in the order UNI-OH $>$ UNI-OMe $>$ UNI-F $>$ UNI-H. A similar tendency was observed in the IMI-X types. The IMI-X types were always more effective than the corresponding UNI-X types. IMI-OH $\left(K_{\mathrm{I}}=600 \mathrm{pM}\right)$ was the most potent inhibitor of ABA 8'-hydroxylase yet tested in an in vitro assay.

\subsection{Structure-activity relationship}

2.5.1. Overall molecular polarity. Based on both the calculated partition coefficient ${ }^{30}$ and the retention factor $(k)$ in reverse phase HPLC analysis (Table 3), UNI-OH and IMI-OH were predicted to be more polar than the other analogs. These two compounds were the most effective inhibitors. Considering only this point, the overall molecular polarity appears to be a significant factor in enzyme inhibition. However, the trend in the activity of other analogs cannot be explained by only the 
molecular polarity; for example, in spite of UNI-H and IMI-H respectively being as polar as UNI-F and IMI-F, UNI-H and IMI-H were much less active than UNI-F and IMI-F. This indicates that the overall molecular polarity of UNI-X and IMI-X has little effect on binding affinity to the active site of CYP707A3.

2.5.2. Triazole vs. imidazole. Imidazole compounds usually have a higher affinity than triazole compounds for the heme of P450 in microsomes. ${ }^{31}$ The pKa value of 1-methylimidazole is 7.12, which is larger than that of 1-methyl-1,2,4-triazole $(3.20)^{32}$; the N4 in imidazole is more basic than that of 1,2,4-triazole. We calculated binding energies between the heme model and 1-methyl-1,2,4-triazole or 1-methylimidazole (Figure 7 and Table 4). The imidazole complex was estimated to be more stable than the triazole complex by $1.92 \mathrm{kcal} \mathrm{mol}^{-1}$, meaning that the imidazole binds to the heme more strongly than the triazole by a factor of ca. 30, explaining why the IMI-analogs are more potent than the corresponding UNI analogs.

2.5.3. Effect of the 3-substituent. The polar functional group at the 3-position contributes energetically to binding at the active site. In both UNI-X and IMI-X, the apparent contribution increases in the order $-\mathrm{F}<-\mathrm{OMe}<-\mathrm{OH}$. The hydroxy group can act as both a donor and an acceptor in hydrogen bonds with the active site, whereas the methoxy and fluorine can act only as an acceptor. The hydrogen acceptor ability of fluorine is weaker than that of oxygen. ${ }^{33}$ These properties may explain the contribution order of $-\mathrm{F}<-\mathrm{OMe}<-\mathrm{OH}$. The effect of these polar groups is apparently larger for the UNI-X types than for the IMI-X types. The differences in structure between UNI-X and IMI-X are the existence of N2" in the azole ring and the conformational profile linked with N2". The conformational preference affected by N2" may be significant. 
2.5.4. Contribution of the conformational preference in the uncomplexed state. Although it is not necessary for the ligand conformation in the protein-ligand complex to be similar to the preferred conformation in the uncomplexed situation, conformational consistency between the uncomplexed and complexed molecules should be advantageous energetically. All the IMI-X types prefer conformers A and $\mathbf{B}$ equally, whereas the UNI-X types vary in conformational preference; UNI-OH prefers $\mathbf{A}$ in a less polar environment and $\mathbf{B}$ in a polar environment; UNI-OMe and UNI-F prefer $\mathbf{B}$ in both environments; and UNI-H prefers A and $\mathbf{B}$ equally. Therefore, the difference in activity between UNI$\mathrm{H}$ and IMI-H is expected to be a straightforward reflection of the difference in the affinity to the active site between the triazole and imidazole rings. In fact, in the above theoretical analysis, imidazole bound to the heme more strongly than triazole by a factor of ca. 30, which agrees with the ratio of $K_{\mathrm{I}}$ $(\mathrm{UNI}-\mathrm{H}) / K_{\mathrm{I}}(\mathrm{IMI}-\mathrm{H})$. The ratio of $K_{\mathrm{I}}(\mathrm{UNI}-\mathrm{X}) / K_{\mathrm{I}}(\mathrm{IMI}-\mathrm{X})$ decreases in the order $-\mathrm{H}(32)>-\mathrm{F}(23)>$ $-\mathrm{OMe}(7)>-\mathrm{OH}(5)$. The smaller influence of $-\mathrm{F},-\mathrm{OMe}$, and $-\mathrm{OH}$ compared to that of $-\mathrm{H}$ may indicate that the conformer $\mathbf{B}$ preference in a polar environment contributes energetically to the affinity to the active site, although the theoretical energy difference between conformers $\mathbf{A}$ and $\mathbf{B}$ in the uncomplexed state cannot completely explain the order $-\mathrm{F}(23)>-\mathrm{OMe}(7)>-\mathrm{OH}(5)$.

\section{Conclusions}

In the present study, we focused on the two polar sites of $S$-(+)-uniconazole (UNI-OH), a strong inhibitor of ABA 8'-hydroxylase, and synthesized 3- and 2"-modified analogs. Conformational analysis and in vitro enzyme inhibition assays yielded new findings about the structure-activity relationship of UNI-OH: (1) by substituting imidazole for triazole, which increases affinity to the heme iron, we identified a more potent compound, IMI-OH; (2) the polar group at the 3-position increases the affinity to the enzyme active site by electrostatic or hydrogen-bonding interactions; (3) the conformer preference in a polar environment partially contributes to the affinity to the active site. 
These findings should be useful for designing potent azole-containing specific inhibitors of ABA 8'hydroxylase.

\section{Experimental}

\subsection{General}

Uniconazole-P was purchased from Wako Pure Chemical Industries, Ltd., Osaka, Japan. (+)-ABA was a gift from Toray Industries Inc., Tokyo, Japan. ${ }^{1} \mathrm{H}$ NMR spectra were recorded with tetramethylsilane as the internal standard using a JEOL JNM-EX270 (270 MHz) and JNM-LA500 (500 MHz) NMR spectrometer. ${ }^{13} \mathrm{C}$ NMR and 2D-correlation NMR experiments were recorded using JNM-LA500 (500 MHz) NMR spectrometer. ${ }^{19}$ F NMR spectra were recorded with trifluorotoluene as the internal standard using a Bruker Avance 400 (380 MHz) NMR spectrometer. High resolution mass spectra (HRMS) were obtained with a JEOL JMS-DX 303 HF mass spectrometer and with a JEOL JMST100LC "AccuTOF". Optical rotations were recorded with a Jasco DIP-1000 digital polarimeter. Circular dichroism (CD) spectra were recorded with a Jasco J-805 spectrophotometer. Column chromatography was performed on silica gel (Wakogel C-200). Purity in two solvent systems $\left(\mathrm{H}_{2} \mathrm{O}-\right.$ $\mathrm{MeOH}$ and $\mathrm{H}_{2} \mathrm{O}-\mathrm{MeCN}$ ) was determined using a Shimadzu LC-10ADVP instrument, and all final compounds were $>99 \%$ pure. X-ray crystallography was performed with a Rigaku AFC-5R diffractometer. Synthetic procedure of the known compounds (UNI-OMe, UNI-H, and IMI-OH): see supplementary data.

\subsection{Synthesis and optical resolution of (E)-1-(1-(4-chlorophenyl)-3-fluoro-4,4-dimethylpent-1- en-2-yl)-1H-1,2,4-triazole (UNI-F)}


Diethylaminosulfur trifluoride $(60 \mu \mathrm{L}, 458 \mu \mathrm{mol})$ was added dropwise into a solution of uniconazole-P (24 mg, $82 \mu \mathrm{mol})$ in dry $\mathrm{CH}_{2} \mathrm{Cl}_{2}(0.5 \mathrm{~mL})$. The mixture was stirred for $15 \mathrm{~min}$ at room temperature, and then quenched with sat. $\mathrm{NH}_{4} \mathrm{Cl}$. The resulting mixture was extracted with EtOAc $(10 \mathrm{~mL} \times 3)$. The organic layer was washed with brine and $\mathrm{H}_{2} \mathrm{O}$, dried over $\mathrm{Na}_{2} \mathrm{SO}_{4}$, and concentrated in vacuo. The residual oil was purified by silica gel column chromatography with $8-25 \%$ EtOAc in hexane to obtain a mixture of UNI-F and the 1-fluorinated compound $(26 \mathrm{mg})$ as colorless oil. The same reaction was repeated using $23 \mathrm{mg}$ of uniconazole-P to obtain $11 \mathrm{mg}$ of the same mixture. The combined mixture was purified by ODS HPLC (Hydrosphere C18, $150 \times 20 \mathrm{~mm}$, YMC; 75\% MeOH; $7 \mathrm{ml} \mathrm{min}{ }^{-1} ; 230 \mathrm{~nm}$ ) to obtain $( \pm)$-UNI-F (11 mg, $38 \mu \mathrm{mol}, 22 \%)$ and 1 (23 mg, $78 \mu \mathrm{mol}, 48 \%)$. ( \pm )-UNI-F: ${ }^{1} \mathrm{H}$ NMR (500 $\left.\mathrm{MHz}, \mathrm{CD}_{3} \mathrm{OD}\right): \delta 0.73\left(9 \mathrm{H}, \mathrm{d},{ }^{4} J_{\mathrm{HF}}=0.9 \mathrm{~Hz}, t\right.$-butyl $), 5.41\left(1 \mathrm{H}, \mathrm{d},{ }^{2} J_{\mathrm{HF}}=44.3 \mathrm{~Hz}, \mathrm{H}-3\right), 7.31(1 \mathrm{H}, \mathrm{s}, \mathrm{H}-$ 1), $7.42\left(2 \mathrm{H}, \mathrm{m}, \mathrm{H}-2^{\prime}\right.$ and H-6'), $7.48\left(2 \mathrm{H}, \mathrm{m}, \mathrm{H}-3^{\prime}\right.$ and H-5'), $8.13\left(1 \mathrm{H}, \mathrm{s}, \mathrm{H}-3{ }^{\prime \prime}\right), 8.67\left(1 \mathrm{H}, \mathrm{d},{ }^{5} J_{\mathrm{HF}}=1.8\right.$ $\mathrm{Hz}, \mathrm{H}-5 ") ;{ }^{13} \mathrm{C}$ NMR (125 MHz, $\left.\mathrm{CD}_{3} \mathrm{OD}\right): \delta 25.8\left(\mathrm{~d},{ }^{4} J_{\mathrm{CF}}=4 \mathrm{~Hz}\right.$, methyls of $t$-butyl), $37.0\left(\mathrm{~d},{ }^{2} J_{\mathrm{CF}}=22\right.$ $\mathrm{Hz}$, tertiary carbon of $t$-butyl), $96.1\left(\mathrm{~d},{ }^{1} J_{\mathrm{CF}}=175 \mathrm{~Hz}, \mathrm{C} 3\right), 130.2\left(\mathrm{C} 3{ }^{\prime}\right.$ and $\left.\mathrm{C} 5{ }^{\prime}\right), 131.5\left(\mathrm{~d},{ }^{5} J_{\mathrm{CF}}=2 \mathrm{~Hz}\right.$, $\mathrm{C}^{\prime}$ and $\left.\mathrm{C}^{\prime}\right), 133.4\left(\mathrm{~d},{ }^{4} J_{\mathrm{CF}}=2 \mathrm{~Hz}, \mathrm{C} 1{ }^{\prime}\right), 135.0\left(\mathrm{~d},{ }^{2} J_{\mathrm{CF}}=18 \mathrm{~Hz}, \mathrm{C} 2\right), 135.2\left(\mathrm{~d},{ }^{3} J_{\mathrm{CF}}=7 \mathrm{~Hz}, \mathrm{C} 1\right), 135.8$ (C4'), $146.0\left(\mathrm{~d},{ }^{4} J_{\mathrm{CF}}=8 \mathrm{~Hz}, \mathrm{C} 5 "\right), 152.7(\mathrm{C} 3 ") ;{ }^{19} \mathrm{~F}$ NMR $\left(377 \mathrm{MHz}, \mathrm{CD}_{3} \mathrm{OD}\right): \delta-190.4\left(\mathrm{~d},{ }^{2} J_{\mathrm{FH}}=44.2\right.$ $\mathrm{Hz}, \mathrm{F}-3)$; UV $\lambda_{\max }(\mathrm{MeOH}) \mathrm{nm}(\varepsilon): 254.0$ (15,300); HRMS (EI): calcd for $\mathrm{C}_{15} \mathrm{H}_{17} \mathrm{ClFN}_{3}[\mathrm{M}]^{+}$293.1095, found 293.1091. The 1-fluorinated compound: ${ }^{1} \mathrm{H}-\mathrm{NMR}\left(270 \mathrm{MHz}, \mathrm{CD}_{3} \mathrm{OD}\right): \delta 0.93(9 \mathrm{H}, \mathrm{s}, t$-butyl), $5.97\left(1 \mathrm{H}, \mathrm{d},{ }^{2} J_{\mathrm{HF}}=45.5 \mathrm{~Hz}, \mathrm{H}-1\right), 6.07\left(1 \mathrm{H}, \mathrm{d},{ }^{4} J_{\mathrm{HF}}=2.5 \mathrm{~Hz}\right.$ and $\left.J=0.6 \mathrm{~Hz}, \mathrm{H}-3\right), 7.11\left(2 \mathrm{H}, \mathrm{m}, \mathrm{H}-2^{\prime}\right.$ and $\left.\mathrm{H}_{-6} 6^{\prime}\right), 7.31\left(2 \mathrm{H}, \mathrm{m}, \mathrm{H}-3^{\prime}\right.$ and $\left.\mathrm{H}-5^{\prime}\right), 7.83\left(1 \mathrm{H}, \mathrm{d},{ }^{6} J_{\mathrm{HF}}=0.9 \mathrm{~Hz}, \mathrm{H}-3^{\prime \prime}\right), 7.94\left(1 \mathrm{H}, \mathrm{s}, \mathrm{H}-5^{\prime \prime}\right) ; \mathrm{UV} \lambda_{\max }$ $(\mathrm{MeOH}) \mathrm{nm}(\varepsilon)$ : 222.8 (14,800); HRMS (EI): calcd for $\mathrm{C}_{15} \mathrm{H}_{17} \mathrm{ClFN}_{3}[\mathrm{M}]^{+}$293.1095, found 293.1092. $( \pm)$-UNI-F (7 mg) were subjected to chiral HPLC under the following conditions: column, Chiralcel OD-H (250 × $10 \mathrm{~mm}$, Daicel); solvent, 3\% 2-propanol in $n$-hexane; flow rate, $3.0 \mathrm{ml} \mathrm{min}{ }^{-1}$; detection, $254 \mathrm{~nm}$. The materials at $t_{\mathrm{R}} 15.1$ and $19.3 \mathrm{~min}$ were collected to give (-)-UNI-F (3 mg) and (+)-UNI-F 
(4 mg), respectively, with an optical purity of each $99.9 \%$. (-)-UNI-F: $[\alpha]_{\mathrm{D}}^{26}-11.7(\mathrm{MeOH}, c 0.195)$;

$(+)-U N I-F:[\alpha]_{\mathrm{D}}^{26}+11.5(\mathrm{MeOH}$, c 0.221$)$.

\subsection{Synthesis of (S,E)-1-(1-(4-chlorophenyl)-3-methoxy-4,4-dimethylpent-1-en-2-yl)-1H- imidazole (IMI-OMe)}

5.3.1. Synthesis of $( \pm)$-IMI-OMe. $( \pm)$-IMI-OMe $(40 \mathrm{mg}, 131 \mu \mathrm{mol})$ was prepared from $( \pm)$-IMI-OH (42 $\mathrm{mg}, 144 \mu \mathrm{mol}, 92 \%$ ) in the similar manner to the preparation of $( \pm$ )-UNI-OMe (see supplementary data). ${ }^{1} \mathrm{H}$ NMR (500 MHz, $\left.\mathrm{CDCl}_{3}\right): \delta 0.74(9 \mathrm{H}, \mathrm{s}, t$-butyl), $3.39(3 \mathrm{H}, \mathrm{s}, \mathrm{OMe}), 3.91(1 \mathrm{H}, \mathrm{s}, \mathrm{H}-3), 6.89$ (1H, s, H-1), 7.08 (1H, s, H-4" or H-5"), 7.16 (1H, s, H-5" or H-4"), 7.23 (2H, m, H-2' and H-6'), 7.39 $\left(2 \mathrm{H}, \mathrm{m}, \mathrm{H}-3^{\prime}\right.$ and $\left.\mathrm{H}-5^{\prime}\right), 7.77$ (1H, s, H-2"); ${ }^{13} \mathrm{C}$ NMR (125 MHz, $\left.\mathrm{CD}_{3} \mathrm{OD}\right): \delta 26.4$ (methyls of $t$-butyl), 35.4 (tertiary carbon of t-butyl), 57.0 (OMe), 84.0 (C3), 120.4 (C5" or C4"), 128.9 (C-3' and C5'), 129.1 (C4" or C5"), 129.9 (C1), 130.1 (C-2' and C-6'), 132.7 (C1' or C4'), 133.9 (C4' or C1'), 135.9 (C2), 137.3 (C2"); UV $\lambda_{\max }(\mathrm{MeOH}) \mathrm{nm}(\varepsilon): 248.4$ (15,600); HRMS (ESI-TOF, positive mode): calcd for $\mathrm{C}_{17} \mathrm{H}_{22} \mathrm{ClN}_{2} \mathrm{O}[\mathrm{M}+\mathrm{H}]^{+}$305.1421, found 305.1419.

5.3.2. Optical resolution of ( \pm )-IMI-OMe. ( $( \pm)$-IMI-OMe $(32 \mathrm{mg})$ was subjected to chiral HPLC under the following conditions: column, Chiralpak AD-H $(250 \times 10 \mathrm{~mm}$, Daicel $)$; solvent, $2 \% 2$ propanol in $n$-hexane; flow rate, $1.0 \mathrm{ml} \mathrm{min}^{-1}$; detection, $254 \mathrm{~nm}$. The materials at $t_{\mathrm{R}} 26.0$ and $35.4 \mathrm{~min}$ were collected to give (-)-IMI-OMe $(14.2 \mathrm{mg})$ and (+)-IMI-OMe $(14.8 \mathrm{mg})$, respectively, with an optical purity of each 99.9\%. (-)-IMI-OMe: $[\alpha]_{\mathrm{D}}^{24}-196.7(\mathrm{MeOH}, c \quad 0.947) ;(+)-\mathrm{IMI}-\mathrm{OMe}:[\alpha]_{\mathrm{D}}^{24}$ +203.8 (MeOH, c 0.967). 


\subsubsection{Determination of the absolute configuration of optically pure IMI-OMe. $S-(-)-\mathrm{IMI}-\mathrm{OH}$}

$(5.5 \mathrm{mg})$ was methylated with the same manner as $( \pm)-\mathrm{IMI}-\mathrm{OH}$. After purified, the methylated compound was subjected to chiral HPLC under the following conditions: column, Chiralpak AD-H

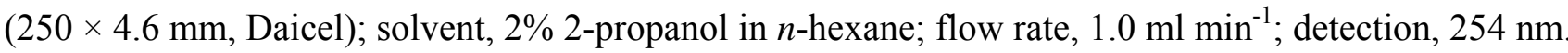
The retention time of the methylated compound agreed with that of (-)-IMI-OMe. Thus the absolute configuration of (-)-IMI-OMe was determined to be $S$.

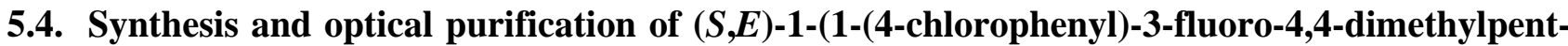
1-en-2-yl)-1H-imidazole (IMI-F)

$( \pm)$-IMI-F (34 mg, $116 \mu \mathrm{mol})$ was prepared from ( \pm )-IMI-OH (625 mg, $2.15 \mathrm{mmol}, 5 \%)$ in the similar manner to the preparation of ( \pm )-UNI-F. ${ }^{1} \mathrm{H}$ NMR $\left(500 \mathrm{MHz}, \mathrm{CD}_{3} \mathrm{OD}\right): \delta 0.72\left(9 \mathrm{H}, \mathrm{d},{ }^{4} \mathrm{~J}_{\mathrm{HF}}=0.6 \mathrm{~Hz}, t\right.$ butyl), $5.26\left(1 \mathrm{H}, \mathrm{d},{ }^{2} J_{\mathrm{HF}}=55.8 \mathrm{~Hz}, \mathrm{H}-3\right), 7.06\left(1 \mathrm{H}, \mathrm{dd}, J=1.2 \mathrm{~Hz},{ }^{5} J_{\mathrm{HF}}=1.2 \mathrm{~Hz}, \mathrm{H}-5 "\right), 7.08(1 \mathrm{H}, \mathrm{s}$, H-1), 7.37 (2H, m, H-2' and H-6'), 7.38 (1H, overlapped with H-2'(6'), H-4"), 7.46 (2H, m, H-3' and H$\left.5^{\prime}\right), 7.91\left(1 \mathrm{H}, \mathrm{d},{ }^{5} J_{\mathrm{HF}}=1.0 \mathrm{~Hz}, \mathrm{H}-2 "\right) ;{ }^{13} \mathrm{C} \mathrm{NMR}\left(125 \mathrm{MHz}, \mathrm{CD}_{3} \mathrm{OD}\right): \delta 25.9\left(\mathrm{~d},{ }^{4} J_{\mathrm{CF}}=3 \mathrm{~Hz}\right.$, methyls of t-butyl), $36.6\left(\mathrm{~d},{ }^{2} J_{\mathrm{CF}}=22 \mathrm{~Hz}\right.$, tertiary carbon of $t$-butyl), $96.1\left(\mathrm{~d},{ }^{1} J_{\mathrm{CF}}=174 \mathrm{~Hz}, \mathrm{C} 3\right), 122.3(\mathrm{C} 4 ")$, 129.2 (C5"), 130.1 (C3' and C5'), 131.4 (C2' and C6'), $133.8\left(\mathrm{~d},{ }^{4} J_{\mathrm{CF}}=2 \mathrm{~Hz}, \mathrm{C} 1 '\right), 134.0\left(\mathrm{~d},{ }^{3} J_{\mathrm{CF}}=7 \mathrm{~Hz}\right.$, C1), $135.3\left(\mathrm{~d},{ }^{2} J_{\mathrm{CF}}=17 \mathrm{~Hz}, \mathrm{C} 2\right), 135.6(\mathrm{C} 4), 138.7\left(\mathrm{~d},{ }^{4} J_{\mathrm{CF}}=4 \mathrm{~Hz}, \mathrm{C} 2 "\right)$; UV $\lambda_{\max }(\mathrm{MeOH}) \mathrm{nm}(\varepsilon)$ : 249.6 (14,300); HRMS (ESI-TOF, positive mode): calcd for $\mathrm{C}_{16} \mathrm{H}_{19} \mathrm{ClFN}_{2}[\mathrm{M}+\mathrm{H}]^{+}$293.1221, found 293.1221. ( \pm )-IMI-F (27 mg) were subjected to chiral HPLC under the following conditions: column, Chiralpak AD-H (250 × $10 \mathrm{~mm}$, Daicel); solvent, 4\% 2-propanol in $n$-hexane; flow rate, $3.0 \mathrm{ml} \mathrm{min}^{-1}$; detection, $254 \mathrm{~nm}$. The materials at $t_{\mathrm{R}} 28.3$ and $44.8 \mathrm{~min}$ were collected to give (-)-IMI-F (10 $\left.\mathrm{mg}\right)$ and $(+)-I M I-F(10 \mathrm{mg})$, respectively, with an optical purity of each 99.9\%. (-)-IMI-F: $[\alpha]_{\mathrm{D}}^{26}-70.1(\mathrm{MeOH}$, c 1.23); (+)-IMI-F: $[\alpha]_{\mathrm{D}}^{26}+78.2(\mathrm{MeOH}$, c 0.99$)$. 


\subsection{Synthesis of IMI-H}

5.5.1. 1-(4-Chlorophenyl)-2-(1H-imidazol-1-yl)-4,4-dimethylpentan-1-one (9). The EtOH (4 mL) solution of 3 (1.50 g, $4.9 \mathrm{mmol}$, see supplementary data), $1 \mathrm{H}$-imidazole $(0.566 \mathrm{~g}, 8.3 \mathrm{mmol})$, and $\mathrm{Na}_{2} \mathrm{CO}_{3}(0.876 \mathrm{~g}, 8.3 \mathrm{mmol})$ were refluxed for $2 \mathrm{~h}$. The mixture was poured into water $(50 \mathrm{~mL})$, and extracted with EtOAc $(50 \mathrm{~mL} \times 3)$. The combined organic layer was washed with brine, dried over $\mathrm{Na}_{2} \mathrm{SO}_{4}$, and concentrated in vacuo. The residual oil was purified by silica gel column chromatography with $60 \%$ EtOAc in hexane to obtain $9(0.634 \mathrm{~g}, 2.2 \mathrm{mmol}, 45 \%)$ as a pale red oil. ${ }^{1} \mathrm{H} \mathrm{NMR}(270 \mathrm{MHz}$, $\left.\mathrm{CDCl}_{3}\right): \delta 0.89(9 \mathrm{H}, \mathrm{s}, t$-butyl), $1.90(1 \mathrm{H}, \mathrm{dd}, J=14.6$ and $8.6 \mathrm{~Hz}, \mathrm{H}-3), 2.16(1 \mathrm{H}, \mathrm{dd}, J=14.6$ and 4.6 Hz, H-3), 5.73 (1H, dd, $J=8.6$ and 4.6 Hz, H-2), 7.06 (1H, s, H-4" or H-5"), 7.07 (1H, s, H-5" or H-4"), 7.47 (2H, m, H-2' and H-6'), 7.62 (1H, m, H-2"), 7.89 (2H, m, H-3' and H-5'); HRMS (ESI-TOF, positive mode): calcd for $\mathrm{C}_{16} \mathrm{H}_{20} \mathrm{~N}_{2} \mathrm{OCl}[\mathrm{M}+\mathrm{H}]^{+} 291.1264$, found 291.1234.

5.5.2. 1-(4-Chlorophenyl)-2-(1H-imidazol-1-yl)-4,4-dimethylpentan-1-ol (10). To a stirred solution of 9 (619 mg, $2.13 \mathrm{mmol})$ in $\mathrm{MeOH}(2 \mathrm{~mL})$ was added $\mathrm{NaBH}_{4}(120 \mathrm{mg}, 3.16 \mathrm{mmol})$. The mixture was stirred for $1.5 \mathrm{~h}$ at room temperature. After quenched with $1 \mathrm{M} \mathrm{HCl}$, the resulting mixture was extracted with EtOAc $(50 \mathrm{~mL} \times 3)$. The organic layer was washed with brine, dried over $\mathrm{Na}_{2} \mathrm{SO}_{4}$, and concentrated in vacuo. The residual oil was purified by silica gel column chromatography with $80 \%$ EtOAc in hexane to obtain 10 (diastereomeric mixture, $608 \mathrm{mg}, 2.08 \mathrm{mmol}, 96 \%$ ) as a colorless oil. ${ }^{1} \mathrm{H}$ NMR $\left(270 \mathrm{MHz}\right.$, acetone- $\left.d_{6}\right)$ of the major diastereomer: $\delta 0.76(9 \mathrm{H}, \mathrm{s}, t$-butyl $), 1.79(1 \mathrm{H}, \mathrm{dd}, J=12.7$ and $2.2 \mathrm{~Hz}, \mathrm{H}-3), 2.12(1 \mathrm{H}, \mathrm{dd}, J=12.7$ and $10.5 \mathrm{~Hz}, \mathrm{H}-3), 4.39(1 \mathrm{H}, \mathrm{m}, \mathrm{H}-2), 4.95(1 \mathrm{H}, \mathrm{m}, \mathrm{H}-1), 6.77$ (1H, m, H-4" or H-5"), 7.02 (1H, m, H-5" or H-4"), 7.16 (2H, m, H-2' and H-6'), 7.24 (2H, m, H-3' and H-5'), 7.33 (1H, m, H-2"); HRMS (ESI-TOF, positive mode): calcd for $\mathrm{C}_{16} \mathrm{H}_{22} \mathrm{ON}_{2} \mathrm{Cl}[\mathrm{M}+\mathrm{H}]^{+} 293.1421$, found 293.1395 . 
5.5.3. (Z)-1-(1-(4-chlorophenyl)-4,4-dimethylpent-1-en-2-yl)-1H-imidazole (11). To a stirred solution of $10(568 \mathrm{mg}, 1.94 \mathrm{mmol})$ in $\mathrm{CH}_{2} \mathrm{Cl}_{2}(20 \mathrm{~mL})$ was added $\mathrm{Et}_{3} \mathrm{~N}(660 \mu \mathrm{L}, 479 \mathrm{mg}, 4.74 \mathrm{mmol})$ and $\mathrm{MsCl}(300 \mu \mathrm{L}, 443 \mathrm{mg}, 3.85 \mathrm{mmol})$ at $0{ }^{\circ} \mathrm{C}$. The mixture was stirred for $5 \mathrm{~h}$ at room temperature under Ar. After quenched with sat. $\mathrm{NaHCO}_{3}$, the organic layer was dried over $\mathrm{Na}_{2} \mathrm{SO}_{4}$, and then concentrated in vacuo. To a stirred solution of the residue in dry DMF $(5 \mathrm{~mL})$ was added $\mathrm{LiCO}_{3}(986$ $\mathrm{mg}, 13.3 \mathrm{mmol}$ ) and $\mathrm{LiBr}$ (monohydrate, $1010 \mathrm{mg}, 9.62 \mathrm{mmol}$ ). The mixture was stirred for $3 \mathrm{~h}$ at $120{ }^{\circ} \mathrm{C}$, and then filtrated at room temperature. Water $(50 \mathrm{~mL})$ was added to the filtrate, and the resulting mixture was extracted with $\mathrm{Et}_{2} \mathrm{O}(25 \mathrm{~mL} \times 3)$. The combined organic layer was washed with brine, dried over $\mathrm{Na}_{2} \mathrm{SO}_{4}$, and concentrated in vacuo. The residual oil was purified by silica gel column chromatography with $40 \%$ EtOAc in hexane to obtain $11(111 \mathrm{mg}, 0.404 \mathrm{mmol}, 21 \%) .{ }^{1} \mathrm{H}$ NMR (270 MHz, CDCl $): \delta 0.85$ (9H, s, t-butyl), $2.45(2 \mathrm{H}, \mathrm{s}, \mathrm{H}-3), 6.27(1 \mathrm{H}, \mathrm{s}, \mathrm{H}-1), 6.70$ (2H, m, H$2^{\prime}$ and $\left.\mathrm{H}-6^{\prime}\right), 6.84(1 \mathrm{H}, \mathrm{dd}, J=1.0$ and $1.0 \mathrm{~Hz}, \mathrm{H}-4$ " or H-5"), $7.11(1 \mathrm{H}, \mathrm{dd}, J=1.0$ and $1.0 \mathrm{~Hz}, \mathrm{H}-5$ " or H-4"), 7.14 (2H, m, H-3' and H-5'), 7.37 (1H, dd, $J=1.0$ and $1.0 \mathrm{~Hz}, \mathrm{H}-2 ")$.

5.5.4. (E)-1-(1-(4-chlorophenyl)-4,4-dimethylpent-1-en-2-yl)-1H-imidazole (IMI-H). The stirred solution of 11 (76 mg, $276 \mathrm{mmol})$ in acetone $(7 \mathrm{~mL})$ in a Pyrex round bottom flask was irradiated with UV light (365 nm, UVP B-100A) for $7 \mathrm{~h}$. After concentrated in vacuo, the residue was purified by silica gel column chromatography with 40\% EtOAc in hexane to obtain IMI-H (26 mg, 95 mmol, 34\%) as colorless oil. ${ }^{1} \mathrm{H}$ NMR (500 MHz, $\left.\mathrm{CDCl}_{3}\right): \delta 0.69\left(9 \mathrm{H}, \mathrm{s}, t\right.$-butyl), $2.75\left(2 \mathrm{H}, \mathrm{s}, \mathrm{H}_{2}-3\right), 6.78(1 \mathrm{H}, \mathrm{s}$, H-1), 7.05 (1H, s, H-4" or H-5"), 7.36 (2H, m, H-2' and -6'), 7.39 (2H, m, H-3' and -5'), 7.43 (1H, s, H5" or H-4"), 7.99 (1H, s, H-2"); ${ }^{13} \mathrm{C}$ NMR (125 MHz, $\mathrm{CDCl}_{3}$ ): $\delta 29.9$ (methyls of $t$-butyl), 33.7 (tertiary carbon of t-butyl), 42.8 (C3), 120.4 (C5" or C4"), 125.7 (C1), 129.4 (C4" or C5"), 129.7 (C3' and C5'), $131.7\left(\mathrm{C}^{\prime}\right.$ and $\left.\mathrm{C}^{\prime}\right), 134.3$ (C1' or $\left.\mathrm{C}^{\prime}\right), 135.6\left(\mathrm{C} 4{ }^{\prime}\right.$ or $\left.\mathrm{C} 1^{\prime}\right), 137.5\left(\mathrm{C} 2{ }^{\prime \prime}\right), 138.8(\mathrm{C} 2)$; $\mathrm{UV} \lambda_{\max }(\mathrm{MeOH})$ 
nm (ع): 254.6 (13,300); HRMS (ESI-TOF, positive mode): calcd for $\mathrm{C}_{16} \mathrm{H}_{20} \mathrm{~N}_{2} \mathrm{Cl}[\mathrm{M}+\mathrm{H}]^{+} 275.1315$, found 275.1295 .

\subsection{The CD analysis of IMI-OH and IMI-F.}

(-)-IMI-OH: CD $\lambda_{\text {ext }}(\mathrm{MeOH}) \mathrm{nm}(\Delta \varepsilon): 265$ (-2.6), 249 (0), $231(+2.4) ;(+)-\mathrm{IMI}-\mathrm{OH}: \mathrm{CD} \lambda_{\text {ext }}(\mathrm{MeOH})$ nm $(\Delta \varepsilon): 265$ (+2.6), $249(0), 231(-2.3)$; (-)-IMI-F: CD $\lambda_{\text {ext }}(\mathrm{MeOH}) \mathrm{nm}(\Delta \varepsilon): 267$ (-3.2), $242(0), 229$ $(+1.5) ;(+)-\mathrm{IMI}-\mathrm{F}: \mathrm{CD} \lambda_{\text {ext }}(\mathrm{MeOH}) \mathrm{nm}(\Delta \varepsilon): 267$ (+2.6), $242(0), 230(-1.2)$.

\subsection{X-ray crystallographic analysis of (-)-UNI-OH, (+)-UNI-F, and (+)-IMI-OH.}

(-)-UNI-OH (3.6 mg) was dissolved in $\mathrm{MeOH}(0.18 \mathrm{~mL})$, followed by adding $\mathrm{H}_{2} \mathrm{O}$. The solution was left at room temperature to obtain colorless cubic. (+)-UNI-F $(115 \mathrm{mg})$ was dissolved in $\mathrm{MeOH}(10$ $\mathrm{mL})$, followed by adding $\mathrm{H}_{2} \mathrm{O}(10 \mathrm{~mL})$. The solution was left at room temperature to obtain colorless prisms. (+)-IMI-OH (6 mg) was dissolved in $\mathrm{MeOH}(0.3 \mathrm{~mL})$, followed by adding $\mathrm{H}_{2} \mathrm{O}$. The solution was left at room temperature to obtain colorless cubic. These structures have been deposited in the Cambridge Crystallographic Data Centre, reference number CCDC 668250 (UNI-OH), CCDC 668251 (IMI-OH), and CCDC 668252 (UNI-F). These data can be obtained free of charge via www.ccdc.cam.ac.uk/data_request/cif, or by emailing data_request@ccdc.cam.ac.uk, or by contacting The Cambridge Crystallographic Data Centre, 12, Union Road, Cambridge CB2 1EZ, UK; fax: +44 1223336033.

\subsection{Enzyme assays}

Kinetic analysis was performed using the detailed protocols described previously. ${ }^{15,34}$ A reaction mixture containing $25 \mu \mathrm{g} \mathrm{mL} \mathrm{mL}^{-1}$ CYP707A3 microsomes, (+)-ABA (final conc.: 0.2-8.0 $\mu \mathrm{M}$ ), inhibitors 
(0 for control, 2-500 nM, in $2 \mu \mathrm{L}$ DMF) and $50 \mu \mathrm{M} \mathrm{NADPH}$ in $50 \mathrm{mM}$ potassium phosphate buffer $(\mathrm{pH} 7.25)$ were incubated for $10 \mathrm{~min}$ at $30^{\circ} \mathrm{C}$. Reactions were initiated by adding NADPH, and stopped by addition of $50 \mu \mathrm{L}$ of $1 \mathrm{M} \mathrm{NaOH}$. The reaction mixtures were acidified with $100 \mu \mathrm{L}$ of $1 \mathrm{M}$ $\mathrm{HCl}$. To extract the reaction products, the mixtures were loaded onto Oasis HLB cartridges $(1 \mathrm{~mL}, 30$ mg; Waters) and washed with $1 \mathrm{~mL}$ of $10 \% \mathrm{MeOH}$ in $\mathrm{H}_{2} \mathrm{O}$ containing $0.5 \% \mathrm{AcOH}$. The enzyme products were then eluted with $1 \mathrm{~mL}$ of $\mathrm{MeOH}$ containing $0.5 \% \mathrm{AcOH}$, and the eluate was concentrated in vacuo. The dried sample was dissolved in $50 \mu \mathrm{L}$ of $\mathrm{MeOH}$, and $10 \mu \mathrm{L}$ were subjected to HPLC. HPLC conditions were: ODS column, Hydrosphere C18 $(150 \times 6.0 \mathrm{~mm}$, YMC); solvent, $40 \% \mathrm{MeOH}$ in $\mathrm{H}_{2} \mathrm{O}$ containing $0.1 \% \mathrm{AcOH}$; flow rate, $1.0 \mathrm{~mL} \mathrm{~min}^{-1}$; detection, $254 \mathrm{~nm}$. Enzyme activity was confirmed by determining the amounts of phaseic acid (PA) in control experiments before each set of measurements. Inhibition constants were determined using the Enzyme Kinetics module of SigmaPlot 10 software $^{35}$ after determining the mode of inhibition by plotting the reaction velocities in the presence and absence of inhibitor on a double-reciprocal plot. Values are reported as mean values with standard errors of the entire datasets. For the non-inhibited enzymatic reaction, the $K_{\mathrm{M}}$ for $(+)$ ABA was calculated to be $0.71 \pm 0.08 \mu \mathrm{M}$, based on 16 separate experiments. All tests were conducted at least three times.

\subsection{Computational method.}

5.9.1. UNI-X and IMI-X. All the minimum-energy conformers of UNI and IMI analogues were generated and minimized using MM3 combined with the molecular dynamics simulation built into CAChe 3.11. ${ }^{36}$ These MM3-minimized structures were fully optimized with density functional theory, using the Becke three parameter hybrid functional (B3LYP) method and the 6-31G(d) basis set in Gaussian $03,{ }^{37}$ followed by a calculation of the harmonic vibrational frequencies at $298 \mathrm{~K}$ at the same level. The single point energies were calculated with B3LYP/6-311++G(2df,2p) level of theory. The 
zero-point energies were scaled by $0.9804 .^{38}$ The geometries and energies in aqueous solution were calculated using the Onsager model and the PCM model in Gaussian 03.

5.9.2. Azole-heme complex model. In the heme model, ferric iron $\left(\mathrm{Fe}^{\mathrm{III}}\right)$ and methyl thiolate as the fifth ligand were used. The propionate side chains of protoporphyrin were protonated in this model. In the initial structures, the methyl group of azoles was oriented to the direction of the propionate side chain of the heme. The dihedral angle $\mathrm{N}^{\mathrm{p}}-\mathrm{Fe}-\mathrm{N}^{\mathrm{az}}-\mathrm{C}^{\mathrm{az}}$ and $\mathrm{Fe}-\mathrm{N}^{\mathrm{az}}$ distance was set to $45^{\circ}$ and $2.1 \AA^{39}$ The geometry optimizations were performed at the B3LYP model with the 6-31+G(d) basis set for C, $\mathrm{H}, \mathrm{O}, \mathrm{N}$, and $\mathrm{S}$, and LanL2DZ basis set for Fe in the spin doublet state. For the azole complex, BSSE corrections were applied during the geometry optimizations.

\subsection{The retention factor $(k)$.}

Column, Hydrosphere C18 (S-5 $\mu \mathrm{m}, 12 \mathrm{~nm}, 150 \times 6 \mathrm{~mm})$; mobile phase, 70\% MeOH; flow rate, $1.0 \mathrm{ml}$ $\min ^{-1}$; detection, $254 \mathrm{~nm}$. The retention factor $(k)$ can be calculated according to the following equation: $k=\left(t_{\mathrm{R}}-t_{\mathrm{M}}\right) / t_{\mathrm{M}}$, where $t_{\mathrm{M}}$ is the dead time that is taken as the first deviation of the baseline following a $5 \mu \mathrm{L}$ injection of $1 \%$ sodium nitrite solution and $t_{\mathrm{R}}$ is the retention time.

\section{Acknowledgments}

We thank Toray Industries Inc., Tokyo, Japan, for the gift of (+)-ABA. Part of this research was carried out using an instrument at the Center for Instrumental Analysis of Shizuoka University. This research was supported by a Grant-in-Aid for Scientific Research (No. 18380192) from the Ministry of Education, Culture, Sports, Science and Technology of Japan. 


\section{Supplementary data}

The synthetic procedures for all compounds, including known compounds and their spectroscopic data, and supplementary data associated with this article can be found in the online version at doi:xx.xxxx/j.bmc.200x.xx.xxx.

\section{References and notes}

1. Funaki, Y.; Ishiguri, T.; Kato, T.; Tanaka, S. J. Pesticide Sci. 1984, 9, 229-236.

2. $\quad$ Funaki, Y.; Oshita, H.; Yamamoto, S.; Tanaka, S.; Kato, T. (Sumitomo Chemical Co.). Ger. Offen. DE3010560, 1980.

3. Izumi, K.; Kamiya, Y.; Sakurai, A.; Oshio, H.; Takahashi, N. Plant Cell Physiol. 1985, 26, 821827.

4. Iwasaki, T.; Shibaoka, H. Plant Cell Physiol. 1991, 32, 1007-1014.

5. Asami, T.; Mizutani, M.; Fujioka, S.; Goda, H.; Min, Y. K.; Shimada, Y.; Nakano, T.; Takatsuto, S.; Matsuyama, T.; Nagata, N.; Sakata, K.; Yoshida, S. J. Biol. Chem. 2001, 276, 25687-25691.

6. $\quad$ Izumi, K.; Nakagawa, S.; Kobayashi, M.; Oshio, H.; Sakurai, A.; Takahashi, N. Plant Cell Physiol. 1988, 29, 97-104.

7. $\quad$ Kitahata, N.; Saito, S.; Miyazawa, Y.; Umezawa, T.; Shimada, Y.; Min, Y. K.; Mizutani, M.; Hirai, N.; Shinozaki, K.; Yoshida, S.; Asami, T. Bioorg. Med. Chem. 2005, 13, 4491-4498.

8. Saito, S.; Okamoto, M.; Shinoda, S.; Kushiro, T.; Koshiba, T.; Kamiya, Y.; Hirai, N.; Todoroki, Y.; Sakata, K.; Nambara, E.; Mizutani, M. Biosci. Biotechnol. Biochem. 2006, 70, 1731-1739.

9. Hirai, N. Abscisic acid. In Comprehensive Natural Products Chemistry Vol. 8; Mori, K. Ed.; Elsevier: Amsterdam, 1999; pp 72-91.

10. Davies, W. J.; Jones, H. G. Abscisic Acid; BIOS Scientific Publishers: Oxford, 1991. 
11. Zeevaart, J. A. D.; Creelman, R. A. Annu. Rev. Plant Physiol. Plant Mol. Biol. 1998, 39, 439-473.

12. Bruzzone, S.; Moreschi, I.; Usai, C.; Guida, L.; Damonte, G.; Salis, A.; Scarfi, S.; Millo, E.; De Flora, A.; Zocchi, E. Proc. Natl. Acad. Sci. USA 2007, 104, 5759-5764.

13. Huang, D.; Jaradat, MR.; Wu, W.; Ambrose, S. J.; Ross, A. R.; Abrams, S. R.; Cutler, A. J. Plant J. 2007, 50, 414-428.

14. Nambara, E.; Marion-Poll, A. Annu. Rev. Plant. Biol. 2005, 56, 165-185.

15. Saito, S.; Hirai, N.; Matsumoto, C.; Ohigashi, H.; Ohta, D.; Sakata, K.; Mizutani, M. Plant Physiol. 2004, 134, 1439-1449.

16. Kushiro, T.; Okamoto, M.; Nakabayashi, K.; Yamagishi, K.; Kitamura, S.; Asami, T.; Hirai, N.; Koshiba, T.; Kamiya, Y.; Nambara, E. ENBO J. 2004, 23, 1647-1656.

17. Yang, S. H.; Choi, D. Biochem. Biophys. Res. Commun. 2006, 350, 685-690.

18. Yang, S. H.; Zeevaart, J. A. D. Plant J. 2006, 47, 675-686.

19. Millar, A. A.; Jacobsen, J. V.; Ross, J. J.; Helliwell, C. A.; Poole, A. T.; Scofield, G.; Reid, J. B.; Gubler, F. Plant J. 2006, 45, 942-954.

20. Destefano-Beltran, L.; Knauber, D.; Huckle, L.; Suttle, J. C. Plant Mol Biol. 2006, 61, 687-697.

21. Umezawa, T.; Okamoto, M.; Kushiro, T.; Nambara, E.; Oono, Y.; Seki, M.; Kobayashi, M.; Koshiba, T.; Kamiya, Y.; Shinozaki, K. Plant J. 2006, 46, 171-182.

22. Okamoto, M.; Kuwahara, A.; Seo, M.; Kushiro, T.; Asami, T.; Hirai, N.; Kamiya, Y.; Koshiba, T.; Nambara, E. Plant Physiol. 2006, 141, 97-107.

23. Katagi, T.; Mikami, N.; Matsuda, T.; Miyamoto, J. J. Pesticide Sci. 1987, 12, 627-633.

24. Meyer, N.; Zeeh, B.; Buschmann, E.; Pommer, E. H. Eur. Pat. Appl. EP 57365, 1982.

25. Funaki, Y.; Oshita, H.; Yamamoto, S.; Tanaka, S.; Kato, T. (Sumitomo Chemical Co.). Jpn. Kokai Tokkyo Koho. JP 54041875, 1979.

26. Tanaka, S. Kagaku to Seibutsu 1986, 24, 180-182 (in Japanese).

27. Takano, H.; Oguri, Y.; Kato, T. J. Pesticide Sci. 1986, 11, 373-378. 
28. Middleton, W. J. Org. Chem. 1975, 40, 574-578.

29. Podust, L. M.; Poulos, T. L.; Waterman, M. R. Proc. Natl. Acad. Sci. USA 2001, 98, 3068-3073.

30. Marvin, ChemAxon, http://www.chemaxon.com/; Csizmadia, F.; Tsantili-Kakoulidou, A.; Panderi, I.; Darvas, F. J. Pharm. Sci. 1997, 86, 865.

31. Ballard, S. A.; Lodola, A.; Tarbit, M. H. Biochem. Pharmacol. 1988, 37, 4643-4651.

32. Catalan, J.; Abboud, J. L. M.; Elguero, J. Adv. Heterocycl. Chem. 1987, 41, 187-274.

33. Desiraju, G.; Steiner, T. The Weak Hydrogen Bond; Oxford University Press: Oxford, 1999.

34. Ueno, K.; Yoneyama, H.; Mizutani, M.; Hirai, N.; Todoroki, Y. Bioorg. Med. Chem. 2007, 15, 6311-6322.

35. SigmaPlot 10; Systat Software, Inc.: Richmond CA, 2006.

36. CAChe, 3.11; Oxford Molecular Ltd.: London, 1998.

37. Gaussian 03 Revision D.01; Gaussian, Inc.: Wallingford CT, 2004.

38. Bauschlicher, Jr., C. W.; Partridge, H. J. Chem. Phys. 1995, 103, 1788-1791.

39. Rupp, B.; Raub, S.; Marian, C.; Höltje, H.-D. J. Comp. Mol. Des. 2005, 19, 149-163. 
Figure and Table Legends

Scheme 1. Synthesis and optical resolution of UNI-OH, UNI-OMe, and UNI-F. Reagents: (i) Chiralpak AD-H; (ii) MeI, NaH; (iii) Chiralpak AD-H; (iv) DAST; (v) Chiralcel OD-H.

Scheme 2. Synthesis of UNI-H and IMI-H. Reagents: (i) $\mathrm{NaOH}$; (ii) $\mathrm{PtO}_{2}$; (iii) $\mathrm{Br}_{2}$; (iv) $1 H-1,2,4-$ triazole, $\mathrm{Na}_{2} \mathrm{CO}_{3}$; (v) $\mathrm{NaBH}_{4}$; (vi) $\mathrm{MsCl}, \mathrm{Et}_{3} \mathrm{~N}$, then $\mathrm{LiBr}, \mathrm{LiCO}_{3}$; (vii) $\mathrm{NaOH}$; (viii) $1 \mathrm{H}$-imidazole, $\mathrm{Na}_{2} \mathrm{CO}_{3}$; (ix) $\mathrm{NaBH}_{4}$; (x) $\mathrm{MsCl}, \mathrm{Et}_{3} \mathrm{~N}$, then $\mathrm{LiBr}, \mathrm{LiCO}_{3}$; (xi) UV $365 \mathrm{~nm}$.

Scheme 3. Synthesis and optical resolution of IMI-OH, IMI-OMe, and IMI-F. Reagents: (i) $\mathrm{K}_{2} \mathrm{CO}_{3}$; (ii) p-chlorobenzaldehyde, $\mathrm{K}_{2} \mathrm{CO}_{3}, \mathrm{Ac}_{2} \mathrm{O}$; (iii) UV $365 \mathrm{~nm}$; (iv) $\mathrm{NaBH}_{4}$; (v) Chiralpak AD-H; (vi) MeI, $\mathrm{NaH}$; (vii) Chiralpak AD-H; (viii) DAST; (ix) Chiralpak AD-H.

Figure 1. Uniconazole (UNI-OH) is a potent inhibitor of ABA 8'-hydroxylase and ent-kaurene oxidase.

Figure 2. Four conformers $\mathbf{A}-\mathbf{D}$ generated by bond rotations of $\mathrm{C} 2-\mathrm{N} 1$ " and $\mathrm{C} 2-\mathrm{C} 3$ in $\mathrm{UNI}-\mathrm{X}(\mathrm{R}=\mathrm{N})$ and IMI-X $(\mathrm{R}=\mathrm{CH})$. Stick models of UNI-OH: carbons, grey; hydrogens, white; oxygens, red; nitrogens, blue; chlorine, light green.

Figure 3. Structures of UNI-X and IMI-X.

Figure 4. Overlaid 3D structures of S-IMI-OH (blue) and S-IMI-F (red) based on the theoretical geometries.

Figure 5. Selected NOESY correlations (arrows) for UNI-X and IMI-X in $\mathrm{CDCl}_{3}$ or methanol- $d_{4}$. 
Figure 6. $3 \mathrm{D}$ structures of UNI-OH (top), UNI-F (middle), and IMI-OH (bottom). (a) X-ray ORTEP structures of the crystalline in $\mathrm{MeOH}-\mathrm{H}_{2} \mathrm{O}$. All are $R$-enantiomers. $R$-UNI-F was obtained as mixed crystals. (b) Overlaid structures. Magenta: the $S$-enantiomers, constructed as mirror images of the Xray structures of the $R$-enantiomers. For UNI-F, the mirror image of another crystal structure is not shown. Cyan: theoretical models of the $S$-enantiomers in $\mathrm{MeOH}$.

Figure 7. The complex between azoles (left: 1-methyl-1,2,4-triazole; right: 1-methylimidazole) and heme model (spin doublet state). The geometries were optimized at the B3LYP/(LanL2DZ, Fe; 6$31+\mathrm{G}(\mathrm{d}), \mathrm{CHNOS})$ level of theory. The distance between Fe and the azole $\mathrm{N}$ atom is $2.17 \AA$ for 1 methyl-1,2,4-triazole and $2.15 \AA$ for 1-methylimidazole. Ball and stick models: carbons, grey; hydrogens, white; oxygens, red; nitrogens, blue; sulfur, yellow; Fe, dark red.

Table 1. The calculated $\mathbf{A} / \mathbf{B}$ conformer ratio of UNI-X and IMI-X

Table 2. Inhibition constants for UNI-X and IMI-X of recombinant CYP707A3

Table 3. The calculated partition coefficient $(\log P)$ and retention factor $(k)$ from reverse phase HPLC analysis

Table 4. Binding energies between the heme model and azoles 
Table 1. The calculated $\mathbf{A} / \mathbf{B}$ conformer ratio of UNI-X and IMI-X

\begin{tabular}{lccccc}
\hline \multirow{2}{*}{ Compound } & \multicolumn{2}{c}{ In gas phase $^{\mathrm{a}}$} & & \multicolumn{2}{c}{ In aqueous phase $^{\mathrm{b}}$} \\
\cline { 2 - 3 } \cline { 5 - 6 } & $\Delta E_{\mathbf{A}-\mathbf{B}}^{\mathrm{c}}\left[\mathrm{kcal} \mathrm{mol}^{-1}\right]$ & $\mathbf{A} / \mathbf{B}$ ratio & & $\Delta E_{\text {A-B }}\left[\mathrm{kcal} \mathrm{mol}^{-1}\right]$ & $\mathbf{A} / \mathbf{B}$ ratio \\
\hline UNI-OH & -2.51 & $99 / 1$ & & +0.87 & $19 / 81$ \\
UNI-OMe & +2.71 & $1 / 99$ & & +1.26 & $11 / 89$ \\
UNI-F & +3.14 & $1 / 99$ & & +0.94 & $17 / 83$ \\
UNI-H & -0.49 & $70 / 30$ & & -0.34 & $64 / 36$ \\
\hline IMI-OH & -0.20 & $58 / 42$ & & -0.05 & $52 / 48$ \\
IMI-OMe & -0.09 & $54 / 46$ & & +0.02 & $49 / 51$ \\
IMI-F & -0.30 & $62 / 38$ & & -0.09 & $54 / 46$ \\
IMI-H & -0.17 & $57 / 43$ & & -0.19 & $58 / 42$ \\
\hline
\end{tabular}

${ }^{\text {a }}$ B3LYP/6-311++G(2df,2p)//B3LYP/6-31G(d).

b $\mathrm{B} 3 \mathrm{LYP} / 6-311++\mathrm{G}(2 \mathrm{df}, 2 \mathrm{p}) / / \mathrm{B} 3 \mathrm{LYP} / 6-31 \mathrm{G}(\mathrm{d})$. Geometry optimization and frequency calculations were performed using the Onsager method, and the single point energy calculations were performed using the IEF-PCM method.

${ }^{\mathrm{c}} \Delta E_{\mathrm{A}-\mathbf{B}}=E_{\mathbf{A}}-E_{\mathbf{B}}$ 
Table 2. Inhibition constants for UNI-X and IMI-X of recombinant CYP707A3

\begin{tabular}{|c|c|c|c|c|c|}
\hline \multirow[b]{2}{*}{$X$} & \multicolumn{2}{|c|}{ UNI-X } & \multicolumn{2}{|c|}{ IMI-X } & \multirow{2}{*}{$\begin{array}{c}K_{\mathrm{I}(\mathrm{UNI}-\mathrm{X})} / K_{\mathrm{I}(\mathrm{IMI}-} \\
\mathrm{X})\end{array}$} \\
\hline & $K_{\mathrm{I}}[\mu \mathrm{M}](\mathrm{SD})$ & $\begin{array}{c}K_{\mathrm{I}(\mathrm{UNI}-\mathrm{X})} / K_{\mathrm{I}(\mathrm{UNI}-} \\
\mathrm{OH})\end{array}$ & $K_{\mathrm{I}}[\mu \mathrm{M}](\mathrm{SD})$ & $\begin{array}{c}K_{\mathrm{I}(\mathrm{IMI}-\mathrm{X})} / K_{\mathrm{I}(\mathrm{IMI}-} \\
\mathrm{OH}) \\
\end{array}$ & \\
\hline $\mathrm{OH}$ & $2.7(0.4)$ & 1 & $0.6(0.2)$ & 1 & 5 \\
\hline $\mathrm{OMe}$ & $8.6(1.4)$ & 3 & $1.2(0.4)$ & 2 & 7 \\
\hline $\mathrm{F}$ & $34(5)$ & 13 & $1.5(0.7)$ & 3 & 23 \\
\hline $\mathrm{H}$ & 450 (99) & 170 & $14(3)$ & 23 & 32 \\
\hline
\end{tabular}


Table 3. The calculated partition coefficient $(\log P)$ and retention factor $(k)$ from reverse phase HPLC analysis

\begin{tabular}{cccccc}
\hline & \multicolumn{2}{c}{ UNI-X } & & \multicolumn{2}{c}{ IMI-X } \\
\cline { 2 - 3 } \cline { 5 - 6 } & $\log P$ & $k$ & & 3.19 & 3.44 \\
\hline $\mathrm{OH}$ & 2.70 & 3.20 & & 3.77 & 8.27 \\
$\mathrm{OMe}$ & 3.28 & 6.33 & & 4.10 & 6.88 \\
$\mathrm{~F}$ & 3.61 & 5.04 & & 4.12 & 6.67 \\
$\mathrm{H}$ & 3.63 & 5.67 & & & \\
\hline
\end{tabular}


Table 4. Binding energies between the heme model and azoles

\begin{tabular}{ccc}
\hline Azole & Binding energy $^{\mathrm{a}}\left[\mathrm{kcal} \mathrm{mol}^{-1}\right]$ & $\Delta\left[\mathrm{kcal} \mathrm{mol}^{-1}\right]$ \\
\hline 1-Me-1,2,4-triazole & -11.14 & 0 \\
1-Me-imidazole & -13.06 & -1.92 \\
\hline
\end{tabular}

${ }^{a}$ Difference in energy between the azole complex and the sum of the azole and heme model. 